\title{
Tourism as (Un)sustainable Production and Consumption
}

\section{Lin Lerpold and Örjan Sjöberg}

\section{INTRODUCTION}

Sustainable and responsible tourism has long been on the agenda and rightly so. For while tourism is often hailed as a source of positive economic and social development, it is also a source of undesirable outcomes not only or even primarily because of the hedonism associated with mass tourism of the "sun, sand and sea" variety. From negative localised social and environmental impacts to global warming, tourism

The original version of this chapter was revised: This chapter is now published open access, and copyright holder has been updated. The correction to this chapter is available at https://doi.org/10.1007/978-3-030-55285-5_16

\section{Lerpold $(\bowtie)$}

Department of Marketing \& Strategy and Center for Sustainability Research, Stockholm School of Economics, Stockholm, Sweden

e-mail: Lin.Lerpold@hhs.se

Ö. Sjöberg

Department of Economics and Center for Sustainability Research, Stockholm School of Economics, Stockholm, Sweden

e-mail: Orjan.Sjoberg@hhs.se

(C) The Author(s) 2021, corrected publication 2021

R. Bali Swain and S. Sweet (eds.), Sustainable Consumption

and Production, Volume II,

https://doi.org/10.1007/978-3-030-55285-5_8 
contributes its share of adverse effects, some of which cannot be avoided even by the ethically conscious visitor (e.g., Hall, 2014; Weeden \& Boluk, 2014). This is so not least because, at a time when "staycation" is gaining ground, tourism by definition requires some form of mobility. That mobility, often by car or air, does little to promote tourism as an alternative to the consumption of material goods that it is sometimes touted as (Gössling, 2000, for a critique). Similarly, while the recreation, pleasure and experiences that tourism provides might be a wiser way of spending increasing disposable incomes than the relentless accumulation of physical possessions, since to many shopping appears to be an important element of the rewarding trip, it is questionable whether tourism is part of the solution. Rather, in many respects it is a part of the problem.

Any such negative effects are compounded by the fact that, globally, tourism and hospitality is one of the fastest growing industries - as the World Tourism Organization points out it accounts for " $10 \%$ of world GDP, 1 in 10 jobs and 7\% of global exports" (UNWTO, 2017: 6). Yet the observation, by Lenzen et al. (2018), that global tourism and the transportation, consumption and shopping that goes with it also accounts for about $8 \%$ of all greenhouse gas emissions should give rise to sobering thoughts. Despite the recent "flight shame" movement and "Greta effect" linked to a decrease in air travel seen in Sweden during 2019, air travel, much of it leisure related, is projected to double over the next decade and a half. As such it does little to alleviate the concern that global trends point in the opposite direction to the one required by the Paris Agreement.

However, not all is gloom and doom. Important parts of the industry are labour intensive, and tourism and hospitality have a record of being inclusive. It often provides the entry point to labour markets and has a claim to being less discriminatory, allowing minority groups and newly arrived migrants better opportunities than is typically the case elsewhere (e.g., UNWTO, 2009). In addition to bringing pecuniary income at destination, tourism can also enhance our understanding of environmental issues, strengthen the appreciation of other cultures and bring people closer together. As such, it has the potential of being a vehicle for education and personal development.

This review of (un)sustainable tourism sets out to map both sides of the coin. As such it focuses on the shifts (and at times trade-offs) between different classes of sustainability concerns, and the variegated emphasis on the local versus the global. It concludes that the global significance of some local circumstances (indeed disorders) is yet to receive the attention it deserves. 


\section{Tourism in the Service of Economic Growth}

It has long been recognised that tourism might help economic growth. As tourism is typically defined as including activities or trips "that take a traveller outside his/her usual environment for less than a year for a main purpose other than to be employed by a resident entity in the place visited" (UN, 2009: 9), this includes developments both at the national and sub-national levels. It is frequently the case that resource poor countries or peripheral areas, including rural ones with limited growth prospects in otherwise healthy economies, are encouraged to engage in tourism and leisure activities to attract visitors. To the extent that such inbound tourism, be it domestic or international in origin, is generated it is also expected to add to local earnings.

Indeed, there is no lack of official pronouncements to this effect (e.g., WTTC, 2019) and there is an extensive set of academic studies of national and regional economies starting with Ghali's (1976) study of Hawai'i. In a steady stream of reports, both direct and indirect effects on growth are recorded and detailed (e.g., Li, Jin, \& Shi, 2018, for a review). It is also possible to relate the effect of the tourism and hospitality industry, delineated to "include that part of the economy which has a common function of supplying tourist needs" (Burkart \& Medlik, 1974: 46) and understand the growth of the tourism development cycle (Butler, 1980), thereby capturing the structural transformation that tourism is often a part of and might contribute to. Summarising much of this work, Mihalic (2013: 660) notes that seen from the vantage point of economic growth, tourism brings development and reduces development gaps; generates foreign currency income; creates employment; and "valorises or adds value" to environmental goods.

It goes without saying that the effects of domestic and foreign tourism might differ along these various dimensions, as would also be the case depending on the purpose for travelling (be it leisure; business and professional; visiting friends and relatives or for religious, educational or medical reasons). Yet, the contribution of tourism to employment is invariably mentioned. It is often held forth as a major benefit not least for peripheral regions that have few other options available to them. As such, it may serve to reduce out-migration and help stabilise demographic change, at least to a degree. To the extent that small and medium-sized enterprises, including family firms, can capitalise on becoming suppliers, the effects on the local economy can be both positive and quite noticeable. The fact 
that jobs often are seasonal and temporary does have its own set of implications however, and may require locals to derive incomes from multiple sources beyond tourism or induce temporary in-migration, including the importation of labour from abroad.

The effects on poverty reduction can therefore be expected to be ambiguous. As with economic growth in general, which is not necessarily pro-poor, much depends on the type of jobs or other forms of income opportunities that tourism generates. For this reason, many discussions have also focused on the creation of backward and forward linkages in the (local) economy (e.g., Telfer \& Wall, 1996). This can be done in quantitative terms, where the standard is to look both at tourism expenditure as such and suppliers' own spending, including local demand induced and resources spent on imports to the national or regional economy (Mihalič, 2013). These tourism income multiplier effects are often used to motivate concessionary terms for inward foreign direct investment (FDI).

In the context of sustainable consumption, also the final point on Mihalič's (2013) list is worth mentioning: the possibility that making the environment more valuable to the local community may serve to improve sustainability. If the surroundings of the local community can be preserved thanks to the fact that in its pristine state that environment represents a resource-be it an ecological or cultural heritage one-that in turn contributes to generating jobs and incomes, there is greater likelihood of it being better taken care of. That might serve ends as varied as biodiversity and the protection of valued cityscapes. It is also in line with the idea that the social and private costs and benefits need to be aligned to provide incentives not to over-use scarce resources.

Success might come at a cost, however. Also, confining the discussion to the realm of economic outcomes, high levels of net tourism receipts might lead to Dutch Disease and a hollowing out of other sectors of the economy (e.g., Capó, Riera Font, \& Rosselló Nadal, 2007; Copeland, 1991; Inchausti-Sintes, 2015). If the hollowing out results in de-industrialisation, it is also likely to affect productivity growth negatively; already at the outset tourism-led growth includes the risk of leading on to lower levels of productivity growth than might otherwise be the case unless specialisation within tourism is embarked upon (e.g., Lanza, Temple, \& Urga, 2003). Such structural distortions add to the problem of leakage, long considered to be a fallout of dependence on tourism for economic growth. Leakage results from high levels of reliance on imports in the tourism sector, but also from high rates of repatriation of profits 
in foreign owned tourism ventures. This not only reduces any positive multiplier effects as might exist but also erodes the capacity of capital accumulation at tourism destinations. As UNCTAD (2013: 13) somewhat bluntly states it,

$[t]$ he presence of transnational corporations (TNCs) in the tourism sector, together with the influx of FDI, leads to financial leakages. While such FDI provides important amounts of capital, TNCs repatriate profits, tend to be vertically integrated with suppliers outside the local economy and often bring in highly skilled international staff that take up the managerial positions. This raises concerns because it could hamper the potential for capital accumulation, integration with local suppliers, transfer of technology and knowledge, and the ability of local staff to upgrade their skills and take up higher value-added jobs.

It might seem, therefore, to be a fine balance between achieving growth through tourism and avoiding imbalances. Indeed, Ghali's (1976: 538) observation that rather than trying to find out how much tourism contributes "the more interesting but more difficult question of "Was it worth it?" is an appropriate one.

\section{TOURISM AND THE SDGS}

A rapidly expanding industry, it is no surprise that tourism also features in the Agenda 2030 (UN, 2015). Accounting for as much as a quarter or even up to a third of the national GDP, not least small island states may rely on tourism and hospitality in ways that are inherently risky and unsustainable. But also, beyond such extremes, the Sustainable Development Goals adopted in 2015 points to the role of the industry under the headings of decent work and economic growth (SDG 8), responsible consumption and production (SDG 12) and life below water (SDG 14). Nowhere is this clearer than in target 8.9 , which stipulates that UN members should "devise and implement policies to promote sustainable tourism that creates jobs and promotes local culture and products" and to do so by 2030. This is to be assessed as the share of jobs in sustainable tourism out of a total number of jobs in tourism. Meanwhile, target 12.b admonishes member states to "develop and implement tools to monitor sustainable impact for sustainable tourism" and to keep track 
of the "[n]umber of sustainable tourism strategies or policies and implemented action plans with agreed monitoring and evaluation tools" (all quotes in this paragraph from UN, 2017).

This has spawned a number of critical reviews setting sight on how the SDGs are framed and what is missing from Agenda 2030 as seen from the vantage point of tourism development. Gender issues, indigenous perspectives, ethical consumption and the possibilities of introducing circular economies are all either rather marginal or missing outright (Boluk, Cavaliere, \& Higgins-Desbiolles, 2019). Furthermore, as is also true of the SDGs in general, there is no explicit general strategy for how these targets are to be reached or prioritised. Implementation is left to individual UN member states and, as Niklasson (2019) shows, the presumption is that economic growth is a necessity to achieve the SDGs irrespective of it being classified as environmental (including SDGs 12 and 14), social and economic (SDG 8). The World Tourism Organization report on tourism and the SDGs for its part notes, on the basis of a survey of a large number of CSR reports from different parts of the industry, that competitiveness and profitability is key to sustainability. This sounds very much like business as usual (Boluk et al., 2019: 855-856), and this despite the fact that it is explicitly noted that "the decoupling of tourism growth from the use of finite natural resources" is imperative (UNWTO, 2017: 35). As for SDG 8, in its efforts to "disentangl[e] tourism's connection with the SDGs in terms of public policy", the World Tourism Organization focuses on the need to create "decent work opportunities, particularly for youth and women". Furthermore, it suggests that "[b]y knowing their supply chain, companies can ask questions of their suppliers and help to ensure commitment to and compliance with the targets" (UNWTO, 2017: 16, 54). Even so, along with procuring local products, it is job creation rather than the safeguarding of decent work that comes to the fore.

\section{Sustainable and Responsible Tourism}

For those familiar with idea of sustainable tourism, this may well seem a tinge anaemic. Accepting the definition promoted by the UN system itself, namely that sustainable tourism is " $[\mathrm{t}]$ ourism that takes full account of its current and future economic, social and environmental impacts, addressing the needs of visitors, the industry, the environment and host communities" (UNEP \& WTO, 2005: 12), it is clear that the scope of 
sustainability as relevant to the industry is wider than that hinted at by the specific SDGs that target tourism as such. The public policy actions outlined suggest as much and the more general provisions of Agenda 2030 are presumably seen as applicable to tourism and hospitality as well (compare UNWTO, 2004). Yet, it remains an empirical issue whether the industry may fly under the radar and escape the attention that would otherwise spur it into more determined and elaborate action. After all, the notion of "eco-tourism", much in vogue by the 1980s and into the 1990s, was widely perceived to be little else than a marketing device (e.g., Wight, 1993). Similarly, by the turn of the millennium, it could credibly be claimed that sustainable tourism had made its entry into "most strategic tourism planning documents" (Hardy, Beeton, \& Pearson, 2002: 475), yet the effects remained uncertain.

The above might suggest that insight into sustainable tourism is lagging behind. Despite early assessments to the effect that little headway was being made (e.g., Wheeller, 1993), this is not quite the case, though there is neither any lack of research on unsustainable outcomes nor on the attempts to promote sustainable tourism. If anything, the list of undesirable effects as evidenced by the research literature has grown over time. By the point in time the flagship Journal of Sustainable Tourism was launched in the early 1990s, it was very clear that tourism, as a prominent consumer of resources, actively contributed to a number of adverse effects of a social, cultural and environmental nature (e.g., McKercher, 1993). Not least, the sheer scale of activities, as expressed in the notion of mass tourism - the "Golden Hordes" as Turner and Ash (1975) had described it-had come to the fore. In due time it induced scholars to discuss carrying capacity (O'Reilly, 1986) that, as Saarinen (2006: 1125) notes, was to carry over to the discussions of sustainable tourism where it "occupies a key position".

As a consequence, and long before responsible tourism became the watchword, alternative forms of tourism entered the agenda (e.g., Cazes, 1989). Butler (1992) usefully summarised the differences between conventional and alternative forms, while (Eadington \& Smith, 1992: 3 ) thought the latter was "broadly defined as forms of tourism that are consistent with natural, social, and community values, and which allow both hosts and guests to enjoy positive and worthwhile interaction and shared experience".

At that point in time, in addition to emphasising long-term objectives and outcomes across all three major areas of sustainability, a move 
from conventional or mass tourism to alternative forms was thought to imply primarily taking the perspectives of the host communities rather than guests and tourism firms. As of today, community-based approaches have not gone out of fashion (e.g., Dangi \& Jamal, 2016) and also more recent initiatives such as "inclusive tourism" (Scheyvens \& Biddulph, 2018) belong here. Yet alternative forms, while possibly the thin edge of the wedge driving developments in a more sustainable direction, has not proven to be the panacea. It is clear that alternative tourism is unlikely to displace mass tourism in its various guises and if current numbers are anything to go by it would seem that the problem worsened over time. This also remains true as mitigation strategies have been developed (addressing issues such as enclave economies and currency leakage, e.g., Freitag, 1994) and as the range of tourism forms and destinations have expanded considerably. Had mass tourism not retained its hold, the notion of over-tourism would not have seen the light of day.

In fact, it seems that the latter phenomenon has been instrumental in allowing the local to make a comeback, as epitomised in the notion of responsible tourism (Boluk \& Weeden, 2016). For while the focus on mass tourism was very much about localised impacts, with the emergence of concerns over climate change, the global commons, at least in part, changed the focus from solely that of impact at destination. This change was a stepwise one and early discussions on tourism and climate change were largely about the consequences to the tourism industry in those countries where the hospitality sector makes an important contribution to the economy (Scott \& Becken, 2010; Wall \& Badke, 1994). Before long, however, tourism as a source of climate change, not just a victim, became a mainstream concern, at least in research (Becken, 2004; Gössling \& Hall, 2006).

By then the notion of green tourism had seen the light of day. With a pedigree that stretches back several decades, as part of his discussion on alternative forms of tourism, Butler (1992: 36) thus found it useful to address the differences between mass tourism and its green opposite number. The latter implied a focus on smaller scale, the prevalence of local ("native" as he had it) developers, development staying within the bounds of local capacity, proactive discussion and planning with respect to (all) conceivable issues of an economic, ecological and social nature. It was a while though before the first comprehensive review of the environmental impact of tourism, that of Gössling (2002), arrived. That review provides a long list of areas of impact, including land cover and land 
use; energy: greenhouse gas emissions; biotic exchange and extinction of species; the spread of disease; and a changing understanding of the environment. While yet other items can be added, including water use, increased use of consumables that are transported long distances and the average trip increasing in length distance-wise, it does point to problems that are of both local and global significance. All in all, it goes well with the idea of responsible tourism, one of the main champions of which (Goodwin, 2012: 8) claimed that:

Responsible Tourism is not about creating long checklists; it is about identifying the economic, social and environmental issues which matter locally and tackling them. The only global issue is climate change.

Save perhaps for local loss of biodiversity potentially being also of global importance and that changing perceptions of the environment acquired in one place may carry over to other settings, this comes across as an apt way of summarising it. Or is it? There are in fact reasons to cast the net a little wider.

\section{Socially Sustainable Tourism}

The beginning of discussions on green tourism and on environmental impacts, more generally, has not been allowed to obscure the realisation that social sustainability is an important dimension of tourism development. As already noted, there are a number of economic and social benefits to be derived from tourism development, perhaps most easily seen in labour market developments, local earning capacity and its contribution to regional development. This is also a prominent justification for countries making an effort to expand this particular industry. It is also precisely here that we may see that the agenda of responsible tourism might benefit from scanning the horizon for global impact more carefully. This section, starting out with a topical aspect of tourism employment that of immigrant labour, is designed to substantiate that observation.

\section{The Positive Side of the Tally: Labour Market and Related Effects}

Integrating immigrants into the labour force of the tourism industry holds both opportunities as well as challenges for host countries and migrants alike. At the nation-state level, challenges of integrating immigrants into 
the labour force often dominate the debate overshadowing the potential positive impacts to further economic growth, enlarged tax base and ageing domestic population with challenges to future pension and health care costs.

For some, migration and tourism are perfect examples of blending production and consumption, as is the case of socio-economically strong youth working in hotels and restaurants abroad for a multi-cultural experience (Williams \& Hall, 2000). For others, because of poverty and few work opportunities in their home country, or as refugees forced to flee because of conflict or climate-related changes, integrating into the host country's labour force is a necessity to survive. The International Labour Organization estimates the number of international migrant workers at 164 million (ILO, 2018). Although the number of these in the broadly defined tourism industry is less well documented, in many countries the tourism industry has been growing faster than the economy as a whole (UNWTO, 2009) and the share of international migrant workers in the sector in countries with available statistics has also grown (Joppe, 2012). International migrant workers have been seen as a solution to the growing demand for labour in the sector, as well as a source of population rejuvenation, labour market efficiency, entrepreneurship, dynamism and diversity (ILO, 2010).

At the nation-state level, both home and host country benefit and face challenges of international migration that are often posited against each other. Potential benefits to the host country include an enlarged tax base and larger employment pool for especially low-skilled labour, while challenges often associate immigration to "integration" problems and increased costs on social welfare, increased crime and populist politics. In tourism, migration presents opportunities and challenges related to labour shortages of both skilled and unskilled labour, along with the challenges of oftentimes temporal dimensions of seasonal demand. King (1995) defines tourism jobs into ranks-of skilled managerial jobs at the upper level of organisational hierarchies where migrants are recruited from highincome countries to locations where managerial experience is relatively lacking, the second rank as intermediate posts such as migrant tour guides and agency representatives with home and host country knowledge and language skills, and finally, the third and largest group involving unskilled migrants moving from low- to high-income countries. 


\section{The Other Side of the Labour Market Coin}

Connecting to the SDG 8 on decent work and economic growth, tourism presents both opportunities in terms of economic growth but also considerable challenges in terms of decent work. Human resources issues are arguably one of the greatest challenges in tourism management (Baum, 2007, 2015), especially related to King's (1995) rank of unskilled migrant labourers. As Wood (1997: 198) once described work in hotels and catering,

[h]ospitality work is largely exploitative, degrading, poorly paid, unpleasant, insecure and taken as a last resort or because it can be tolerated in light of wider social and economic commitments and constraints.

Though this bleak description of working conditions in the tourism sector may be overly generalised and historic, Baum (2015) argues that the working conditions have only marginally improved because of cheap mobile labour, over-education of school leaving population, deskilling technologies, focus on cost cutting and higher unemployment has continued the shift towards employer power in developed countries.

Precarious work refers to the changing modes of differentiation of migrant workers that give them unequal chances in market competition (Castles, 2015). Though 1 in 10 jobs globally are said to be in tourism (UNWTO, 2017), compared to environmental issues, working conditions and human resource issues in the industry have been largely and surprisingly ignored by academic scholarship (Baum, Kralj, Robinson, \& Solnet, 2016). In their overview of the literature on precarity in the work context, Alberti, Bessa, Hardy, Trappmann, and Umney (2018) characterise precarious work by lack of security and predictability and which manifests as material and psycho-social depravation. Robinson, Martins, Solnet, and Baum (2019) argue that the tourism industry sustains this precarity vis-à-vis its employment practices through the political and social neo-liberal market agenda, thus benefitting employers, especially in the tourism industry, to the detriment of workers.

Of largest academic concern seems to be the level of wages and working conditions. According to a study by APEC (2017), tourism workers earn on average less than half of the all-industries average in many countries, in both developed and developing nations, for instance, in Canada, New Zealand, Philippines and Indonesia. Women and young 
people are most marginalised. Though it is acknowledged that there are many tourism companies that commit to broad-based corporate social responsibility and have high standards on ethical employment, allegations of tourism work bordering on "modern slavery" have been documented. For instance, in a study of the UK hospitality sector, tourism work included child labour, sex work, trafficking and forced labour (Armstrong, 2016). Indeed, different forms of modern slavery in the tourism industry are well documented in ILO's case studies database, involving child labour, sex work, human trafficking and bonded labour, in both developing and developed nations. Cheer (2018) adds an aspect, linking the geographies of marginalisation and modern slavery to tourism research and includes the growing practice of so-called orphanage tourism in less developed contexts where good intentions are commodified by orphanages together with "do-good" experience tourists. In much of the extant literature on social sustainability challenges in the tourism industry, it is argued that the neo-liberal market or capitalist system is oftentimes responsible for sustaining deep social cleavages and economic inequalities, particularly in tourism, thereby extending the precarious nature of tourism work itself (Robinson et al., 2019).

\section{Other Effects}

Serious as the exploitation of labour is - and it is truly serious and often criminal-it is neither the beginning nor end of the social sustainability of tourism. Also, in addition to the effects on communities and the economics of leakage, that is, consumption of local vs non-local products and the effects on local business this implies, there are other phenomena that from a social sustainability point of view warrant consideration. One of the most basic is the relationship between tourism and forms of crime that do not primarily issue from or are part of labour relations (Jones, Barclay, \& Mawby, 2012; Botterill \& Jones, 2010a; Pizam, 1999; Ryan, 1993). Yet, despite research over several decades, there appears to be few truly conclusive and universally valid results as to the effects of tourism growth on crime rates. Save for the observation that tourists are more likely to be victims of acquisitive crimes than are locals, there is little systematic evidence to suggest that crime rates increase along with tourism growth or that either locals or tourists themselves suffer the most from any increased incidence as can be observed in several studies (e.g., 
Biagi \& Detotto, 2014; Chesney-Lind \& Lind, 1986; de Albuquerque \& McElroy, 1999; Pizam, 1982).

Although tourists may be both offenders and victims, and the fact that crime at times and in specific places clearly does increase alongside the growth of tourism arrivals, this lack of clarity might be a result of criminologists (as opposed to tourism researchers) having "avoided discussion of tourism as a crime generator" (Mawby, Barclay, \& Jones, 2010: 320). It also probably accounts for the observation that much of that research focuses on the real or perceived impact of crime on the reputation of destinations (e.g., Botterill \& Jones, 2010b), just as security threats may also deter tourism (Fourie, Rosselló-Nadal, \& Santana-Gallego, 2020). Corruption, for its part, may not just deter tourism (Papathanassis, 2019), but might also put visitors and locals at serious risk. This may include the violation of building codes, with the consequences of the 26 November 2019 earthquake in Albania only being the most recent example (at which point two hotels collapsed, a number of alleged perpetrators subsequently being brought before court; $K J, 2019$ ). Likewise, it is easy to imagine that corrupt practices may negatively impact the natural environment or cultural heritage.

Another issue that has become increasingly salient is "touristification", gentrification and displacement (Cocola-Gant, 2018; Gotham, 2005; Ioannides, Röslmaier, \& van der Zee, 2019; Sequera \& Nofre, 2018). Often part of discussions on over-tourism, and not infrequently blamed on the advent of digital platforms such as Airbnb, the phenomenon is not as recent as one might be led to believe. By way of an example, it has long been recognised that the proliferation of second homes may contribute to gentrification (Coppock, 1977; Paris, 2009). Thus, while "[t]he perception of second-home landscapes as elite landscapes has dominated not least the literature originating from the Anglosphere" (Müller \& Hoogendoorn, 2013: 359) and might not be applicable everywhere, also in egalitarian societies such as the Nordic ones "an increasing polarisation of second-home ownership reserving the most attractive spots to high-income households" can be observed.

That said, in metropolitan areas and at major tourist destinations, global tourists often act as "international gentrifying elites" (GravariBarbas \& Guinand, 2017) that combine the pursuit of leisure activities with investment opportunities. This implies the conversion of residential space for the locals to accommodation for tourists with out-migration, at 
times also outright displacement, of the residents and a changing structure of local area services on offer as a result (e.g., Cocola-Gant, 2018; Yrigoy, 2019). Likely to be most severely felt in places of real or perceived over-tourism, the triggering events of such gentrification may of course differ-from "upscale culture consumption" to heritage restoration to various efforts to mimic the Bilbao effect with a view to harnessing global capital (Gravari-Barbas \& Guinand, 2017; McNeill, 2000)—but the outcome is one where residents at destination start objecting to tourism and tourists.

The role of the digital economy in all of this is not always easy to disentangle. On the one hand, the role of new ways of coordinating demand and supply of accommodation might be an important factor in the continued growth of tourism (e.g., Dodds \& Butler, 2019). On the other, renting out to holiday makers is not a new phenomenon (the ease with which it takes place might be though) and at the level of principle, the sharing economy and peer-to-peer exchanges of resources and assets else not used to capacity would be as favourable to tourism as to other domains. In short, it carries a promise of more sustainable consumption. However, as Gössling and Hall (2019: 90) argue, the sharing economy is often eclipsed by the collaborative economy with its stronger focus on entrepreneurial opportunities. This includes opportunities made use of by the large and distant "global corporations [that] 'collect' a share of revenue even from the smallest social entrepreneurs", thereby implying that "small and medium-sized enterprises now support the very structures the sharing economy was thought to overcome".

\section{CONCLUSION}

“Tourists are consumers, not anthropologists", McKercher (1993: 6) noted, and consumption is therefore integral to tourism. Tourism is also an industry that for the most part operates on the principles of profit maximisation; indeed, the UNWTO (2017) underlines that sound economic health of tourism industry firms is a sine qua non for the benefits that tourism delivers, chief among which is a dependable source of income at destination. Tourism provides much needed jobs and incomes not least in areas else potentially peripheral to the economic mainstream. Those else disadvantaged in the labour market - the young, the newly arrived, etc.- stand to gain from the expansion of tourism, and often do. In no small part, the capacity of tourism to offer such opportunities 
emerge from its sheer volume and its continued growth, which in turn is dependent on its apparent universal attraction to those who come to enjoy a measure of affluence or find tourism activities increasingly affordable.

Not all potential destinations might be so favoured. As the notion of a resort life cycle suggests formerly successful destinations run the risk of fading away. If rejuvenation cannot be engineered, the benefits as might have accrued are also likely to go into the reverse. Something similar can be said of developments at more aggregate levels: what happens to the national economy if a country, as a favoured tourist destination, falls from grace? And what might happen if, say, for reasons of climate change mitigation needs, tourism goes into global decline? Academic research, at least, appears to have given that scenario little thought.

Yet, with growth, a range of adverse effects often follow, several of which have been touched upon in this overview of sustainable tourism. It is important to underline that these effects rarely are only local in nature, but may have repercussions well beyond the site where these adverse effects are generated or immediately visible. Climate change impacts are the obvious example, affecting the global commons as greenhouse gas emissions do; the fact that tourism by definition requires mobility adds to the strain. Less obvious, but equally a matter of serious concern, is the social unsustainability implied by precarious work, including trafficking in humans and the bonded labour that is part of modern slavery. While research on issues of this kind has picked up, at least within tourism studies, the global implications of it remain less visible than the local dimension of the suffering it entails. Clearly more could be done, potentially building on the pioneering work on the tourism migration system by Hall and Williams (2002). The same could be said of the leisure-andinvestment complex that results in touristification and gentrification. It is not that research on sustainable tourism has turned its back on international investment flows or the nature of financialisation, only that it has not been given the same level of attention as is the case, for instance, in island development (Clark, 2013) or urban change (Weber, 2010). It would, no doubt, be gratifying to prove Mitchell's (1997: 304) prescient observation wrong:

by effectively masking the degree to which capital must be located, the ideology of globalization allows local officials, along with local business people and property owners, to argue that they have no choice but to 
prostrate themselves before the god Capital, offering not just tax and regulatory inducements, but also extravagant convention centers, downtown tourist amusements, up-market, gentrified restaurant and bar districts, and even occasional public investment in such amenities as museums, theatres and concert halls.

As this chapter bears witness to, it is doubtful whether the SDGs can help mitigate, let alone stamp out, the adverse effects observed. A lack of success on that score would be unfortunate, as tourism is not just a favourite pastime of a large and growing part of the world's population, as a product and as an object of consumption, it also has a number of positive traits that are well worth preserving.

Acknowledgements This work was partially funded by the Swedish government research council for sustainable development Formas in the project, "The tourist industry and its contribution to sustainable development: Social networks and social capital in the employment of immigrants".

\section{REFERENCES}

Alberti, G., Bessa, I., Hardy, K., Trappmann, V., \& Umney, C. (2018). In, against and beyond precarity: Work in insecure times. Work, Employment \& Society, 32(3), 447-457.

APEC. (2017). Developing the tourism workforce of the future in the APEC Region. Singapore: Tourism Working Group, Asia-Pacific Economic Cooperation Secretariat.

Armstrong, R. (2016). Modern slavery: Risks for the UK hospitality industry. Progress in Responsible Tourism, 5(1), 67-78.

Baum, T. (2007). Human resources in tourism: Still waiting for change. Tourism Management, 28(6), 1383-1399.

Baum, T. (2015). Human resources in tourism: Still waiting for change? A 2015 reprise. Tourism Management, 50, 204-212.

Baum, T., Kralj, A., Robinson, R. N. S., \& Solnet, D. J. (2016). Tourism workforce research: A review, taxonomy and agenda. Annals of Tourism Research, 60, 1-22.

Becken, S. (2004). How tourists and tourism experts perceive climate change and carbon-offsetting schemes. Journal of Sustainable Tourism, 12(4), 332-345.

Biagi, B., \& Detotto, C. (2014). Crime as tourism externality. Regional Studies, $48(4), 693-709$. 
Boluk, K. A., Cavaliere, C. T., \& Higgins-Desbiolles, F. (2019). A critical framework for interrogating the United Nations Sustainable Development Goals 2030 Agenda in tourism. Journal of Sustainable Tourism, 27(7), 847-864.

Boluk, K., \& Weeden, C. (2016). Responsible tourism. In J. Jafari \& H. Xiao (Eds.), Encyclopedia of tourism (pp. 794-795). Cham: Springer.

Botterill, D., \& Jones, T. (2010a). Tourism and crime: Key themes. Woodeaton, Oxford: Goodfellow Publishers.

Botterill, D., \& Jones, T. (2010b). Introduction: Tourism studies and criminology. In D. Botterill \& T. Jones (Eds.), Tourism and crime: Key themes (pp. 1-18). Woodeaton, Oxford: Goodfellow Publishers.

Burkart, A. J., \& Medlik, S. (1974). Tourism: Past, present and future. London: Heinemann.

Butler, R. W. (1980). The concept of the tourist area life-cycle of evolution: Implications for management of resources. Canadian Geographer/Le Géograph canadien, 24(1), 5-12.

Butler, R. W. (1992). Alternative tourism: The thin edge of the wedge. In V. L. Smith \& W. R. Eadington (Eds.), Tourism alternatives: Potentials and pitfalls in the development of tourism (pp. 31-46). Philadelphian, PA: University of Pennsylvania Press.

Capó, J., Riera Font, A., \& Rosselló Nadal, J. (2007). Dutch disease in tourism economies: Evidence from the Balearics and the Canary Islands. Journal of Sustainable Tourism, 15(6), 615-627.

Castles, S. (2015). Migration, precarious work and rights: Historical and current perspectives. In C.-U. Schierup, R. Munck, B. Likić-Brborić, \& A. Neergaard (Eds.), Migration, precarity, and global governance: Challenges and opportunities for labour (pp. 46-67). Oxford: Oxford University Press.

Cazes, G. H. (1989). Alternative tourism: Reflections on an ambiguous concept. In T. V. Singh, H. Leo Theuns, \& F. M. Go (Eds.), Towards appropriate tourism: The case of developing countries (pp. 117-126). Frankfurt am Main: Peter Lang.

Cheer, J. M. (2018). Geographies of marginalization: Encountering modern slavery in tourism. Tourism Geographies, 20(4), 728-732.

Chesney-Lind, M., \& Lind, I. Y. (1986). Visitors as victims: Crimes against tourists in Hawaii. Annals of Tourism Research, 13(2), 167-191.

Clark, E. (2013). Financialization, sustainability and the right to the island: A critique of acronym models of island development. Journal of Marine and Island Cultures, 2(2), 128-136.

Cocola-Gant, A. (2018). Tourism gentrificaiton. In L. Lees \& M. Phillips (Eds.), Handbook of gentrification studies (pp. 281-293). Cheltenham: Edward Elgar.

Copeland, B. R. (1991). Tourism, welfare and de-industrialization in a small open economy. Economica, 58(232), 515-529. 
Coppock, J. T. (1977). Issues and conflicts. In J. T. Coppock (Ed.), Second homes: Curse or blessing? (pp. 195-215). Oxford: Pergamon Press.

Dangi, T. B., \& Jamal, T. (2016). An integrated approach to "sustainable community-based tourism". Sustainability, $8(5), 475$.

de Albuquerque, K., \& McElroy, J. (1999). Tourism and crime in the Caribbean. Annals of Tourism Research, 26(4), 968-984.

Dodds, R., \& Butler, R. (2019). The phenomenon of overtourism: A review. International Journal of Tourism Cities, 5(4), 519-528.

Eadington, W. R., \& Smith, V. L. (1992). Introduction: The emergence of alternative forms of tourism. In V. L. Smith \& W. R. Eadington (Eds.), Tourism alternatives: Potentials and pitfalls in the development of tourism (pp. 1-12). Philadelphia, PA: University of Pennsylvania Press.

Fourie, J., Rosselló-Nadal, J., \& Santana-Gallego, M. (2020). Fatal attraction: How security threats hurt tourism. Journal of Travel Research, 59(2), 209219.

Freitag, T. G. (1994). Enclave tourism development for whom the benefits roll? Annals of Tourism Research, 21(3), 538-554.

Ghali, M. A. (1976). Tourism and economic growth: An empirical study. Economic Development and Cultural Change, 24(3), 527-538.

Goodwin, H. (2012). Ten years of Responsible Tourism: An assessment. Progress in Responsible Tourism, 2(1), 4-33.

Gössling, S. (2000). Tourism: A sustainable development option? Environmental Conservation, 27(3), 223-224.

Gössling, S. (2002). Global environmental consequences of tourism. Global Environmental Change, 12(4), 283-302.

Gössling, S., \& Hall, C. M. (2006). Uncertainties in predicting tourist flows under scenarios of climate change. Climatic Change, 79(3-4), 163-173.

Gössling, S., \& Hall, C. M. (2019). Sharing versus collaborative economy: How to align ICT developments and the SDGs in tourism? Journal of Sustainable Tourism, 27(1), 74-96.

Gotham, K. F. (2005). Tourism gentrification: The case of New Orleans' Vieux Carre (French Quarter). Urban Studies, 42(7), 1099-1121.

Gravari-Barbas, M., \& Guinand, S. (2017). Introduction: Addressing tourismgentrification in contemporary metropolises. In $M$. Gravari-Barbas \& $S$. Guinand (Eds.), Tourism and gentrification in contemporary metropolises: International perspectives (pp. 1-21). Abingdon: Routledge.

Hall, C. M. (2014). You can check out anytime you like but you can never leave: Can ethical consumption in tourism ever be sustainable? In C. Weeden \& K. Boluk (Eds.), Managing ethical consumption in tourism (pp. 32-55). Abingdon: Routledge.

Hall, C. M., \& Williams, A. M. (2002). Tourism and migration: New relationships between production and consumption. Dordrecht: Springer. 
Hardy, A., Beeton, R. J. S., \& Pearson, L. (2002). Sustainable tourism: An overview of the concept and its position in relation to conceptualisations of tourism. Journal of Sustainable Tourism, 10(6), 475-496.

ILO. (2010). International labour migration: A rights-based approach. Geneva: International Labour Office.

ILO. (2018). Global estimates on international migrant workers: Results and methodology (2nd ed.). Geneva: International Labour Office.

Inchausti-Sintes, F. (2015). Tourism: Economic growth, employment and Dutch Disease. Annals of Tourism Research, 54, 172-189.

Ioannides, D., Röslmaier, M., \& van der Zee, E. (2019). Airbnb as an instigator of 'tourism bubble' expansion in Utrecht's Lombok neighbourhood. Tourism Geographies, 21(5), 822-840.

Jones, C., Barclay, E., \& Mawby, R. (Eds.). (2012). The problem of pleasure: Leisure, tourism and crime. London: Routledge.

Joppe, M. (2012). Migrant workers: Challenges and opportunities in addressing tourism labour shortages. Tourism Management, 33(3), 662-671.

King, R. (1995). Tourism, labour and international migration. In A. Montanari \& A. M. Williams (Eds.), European tourism: Regions, spaces and restructuring (pp. 177-190). Chichester: Wiley.

KJ. (2019, 16 December). Tërmeti tragjik, 9 të arrestuarit dalin sot përpara Gjykatës, Koha Jonë, Tirana. Retrieved from https://kohajone.com/termetitragjik-9-te-arrestuarit-dalin-sot-perpara-gjykates/. Accessed 16 December 2019.

Lanza, A., Temple, P., \& Urga, G. (2003). The implications of tourism specialisation in the long run: An econometric analysis for 13 OECD economies. Tourism Management, 24(3), 315-321.

Lenzen, M., Sun, Y.-Y., Faturay, F., Ting, Y.-P., Geschke, A., \& Malik, A. (2018). The carbon footprint of global tourism. Nature Climate Change, 8, 522-528.

Li, K. X., Jin, M., \& Shi, W. (2018). Tourism as an important impetus to promoting economic growth: A critical review. Tourism Management Perspectives, 26, 135-142.

Mawby, R. I., Barclay, E., \& Jones, C. (2010). Tourism and victimization. In S. G. Shoham, P. Knepper, \& M. Kett (Eds.), International handbook of victimology (pp. 319-340). Boca Raton, FL: CRC Press.

McKercher, B. (1993). Some fundamental truths about tourism: Understanding tourism's social and environmental impacts. Journal of Sustainable Tourism, I(1), 6-16.

McNeill, D. (2000). McGuggenisation? National identity and globalisation in the Basque country. Political Geography, 19(4), 473-494.

Mihalič, T. (2013). Economic impacts of tourism, particularly its potential contribution to economic development. In C. A. Tisdell (Ed.), Handbook of 
tourism economics: Analysis, new applications and case studies (pp. 645-682). Singapore: World Scientific.

Mitchell, D. (1997). The annihilation of space by law: The roots and implications of anti-homeless laws in the United States. Antipode, 29(3), 303-335.

Müller, D. K., \& Hoogendoorn, G. (2013). Second homes: Curse or blessing? A review 36 years later. Scandinavian Journal of Hospitality and Tourism, 13(4), 353-369.

Niklasson, L. (2019). Improving the sustainable development goals: Strategies and the governance challenge. Abingdon: Routledge.

O'Reilly, A. M. (1986). Tourism carrying capacity: Concept and issues. Tourism Management, 7(4), 254-258.

Papathanassis, A. (2019). The impact of corruption on travelers' perceptions and preferences. Tourism Review, 74(4), 795-814.

Paris, C. (2009). Re-positioning second homes within housing studies: Household investment, gentrification, multiple residence, mobility and hyperconsumption. Housing, Theory and Society, 26(4), 292-310.

Pizam, A. (1982). Tourism and crime: Is there a relationship? Journal of Travel Research, 20(3), 7-10.

Pizam, A. (1999). A comprehensive approach to classifying acts of crime and violence at tourism destinations. Journal of Travel Research, 38(1), 5-12.

Robinson, R. N. S., Martins, A., Solnet, D., \& Baum, T. (2019). Sustaining precarity: Critically examining tourism and employment. Journal of Sustainable Tourism, 27(7), 1008-1025.

Ryan, C. (1993). Crime, violence, terrorism and tourism: An accidental or intrinsic relationship? Tourism Management, 14(3), 173-183.

Saarinen, J. (2006). Traditions of sustainability in tourism studies. Annals of Tourism Research, 33(4), 1121-1140.

Scheyvens, R., \& Biddulph, R. (2018). Inclusive tourism development. Tourism Geographies, 20(4), 589-609.

Scott, D., \& Brecken, S. (2010). Adapting to climate change and climate policy: Progress, problems and potentials. Journal of Sustainable Tourism, 18(3), 283-295.

Sequera, J., \& Nofre, J. (2018). Shaken, not stirred: New debates on touristification and the limits of gentrification. City, 22(5-6), 843-855.

Telfer, D. J., \& Wall, G. (1996). Linkages between tourism and food production. Annals of Tourism Research., 23(3), 635-653.

Turner, L., \& Ash, J. (1975). The golden hordes: International tourism and the pleasure periphery. London: Constable.

UN. (2009). Tourism satellite account: Recommended methodological framework 2008. Studies in Methods F 80/Rev. 1. New York: Statistics Division, Department of Economic and Social Affairs, United Nations. 
UN. (2015). Resolution adopted by the General Assembly on 25 September 2015, 70/1. Transforming our world: The 2030 Agenda for Sustainable Development. General Assembly, A/RES/70/1. New York: United Nations. UN. (2017). Resolution adopted by the General Assembly on 6 July 2017, $71 / 313$. Work of the Statistical Commission pertaining to the 2030 Agenda for Sustainable Development. General Assembly, A/RES/71/313. New York: United Nations.

UNCTAD. (2013, 28 January). Sustainable tourism: Contribution to economic growth and sustainable development. Trade and Development Board, TD/B/C.I/EM.5/2. Geneva: United Nations Conference on Trade and Development.

UNEP \& WTO. (2005). Making tourism more sustainable: A guide for policy makers. Paris and Madrid: United Nations Environmental Programme and World Tourism Organization, Trade and Development Board.

UNWTO. (2004). Indicators of sustainable development for tourism destinations: A guidebook. Madrid: World Tourism Organization.

UNWTO. (2009). Tourism and migration: Exploring the relationship between two global phenomena. Madrid: World Tourism Organization.

UNWTO. (2017). Tourism and the sustainable development goals-Journey to 2030. Madrid: World Tourism Organization.

Wall, G., \& Badke, C. (1994). Tourism and climate change: An international perspective. Journal of Sustainable Tourism, 2(4), 193-203.

Weber, R. (2010). Selling city futures: The financialization of urban redevelopment policy. Economic Geography, 86(3), 251-274.

Weeden, C., \& Boluk, K. (Eds.). (2014). Managing ethical consumption in tourism. Abingdon: Routledge.

Wheeller, B. (1993). Alternative tourism: A deceptive ploy. In C. P. Cooper \& A. Lockwood (Eds.), Progress in tourism, recreation and hospitality management (Vol. 4, pp. 140-145). Chichester: Wiley.

Wight, P. (1993). Ecotourism: Ethics or eco-sell? Journal of Travel Research, 31(3), 3-9.

Williams, A. M., \& Hall, C. M. (2000). Tourism and migration: New relationships between production and consumption. Tourism Geographies, 2(1), $5-27$.

Wood, R. C. (1997). Working in hotels and catering (2nd ed.). London: Routledge.

WTTC. (2019). Economic impact of travel and tourism. London: World Travel and Tourism Council.

Yrigoy, I. (2019). Rent gap reloaded: Airbnb and the shift from residential to touristic rental housing in the Palma Old Quarter in Mallorca. Spain. Urban Studies, 56(13), 2709-2726. 
Open Access This chapter is licensed under the terms of the Creative Commons Attribution 4.0 International License (http://creativecommons.org/licenses/ by $/ 4.0 /$ ), which permits use, sharing, adaptation, distribution and reproduction in any medium or format, as long as you give appropriate credit to the original author(s) and the source, provide a link to the Creative Commons license and indicate if changes were made.

The images or other third party material in this chapter are included in the chapter's Creative Commons license, unless indicated otherwise in a credit line to the material. If material is not included in the chapter's Creative Commons license and your intended use is not permitted by statutory regulation or exceeds the permitted use, you will need to obtain permission directly from the copyright holder.

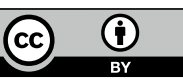

